\title{
Múszaki kerámiák kutatása és ipari alkalmazásaik: átlátszó AlON kerámiaanyagok előállítási módszerei és tulajdonságai
}

\section{Research on Technical Ceramics and their Industrial Application: Preparation Techniques and Properties of Transparent AlON Ceramics}

\author{
Balázsi Csaba, Furkó Mónika, Szira Fruzsina, Balázsi Katalin \\ Magyar Tudományos Akadémia, Energiatudományi Kutatóközpont, Müszaki Fizikai és Anyagtudományi \\ Intézet, Budapest, Magyarország, balazsi.csaba@energia.mta.hu
}

\begin{abstract}
Aluminium oxynitride (AlON) has a unique thermal and chemical stability that makes it the perfect candidate for a wide range of applications. This article provides a brief description and comparison of the most common AlON preparation methods along with their advantages and disadvantages. Although there has been extensive research on the material, especially more recently because of increased commercial interest, extensive systematic powder synthesis and processing studies have not been carried out to determine alternate, more cost efficient routes to fully dense transparent bodies. Further optimization of reaction sintering and transient liquid phase sintering could be important processing routes.
\end{abstract}

Keywords: AlON, transparent ceramics, hot isostatic pressing (HIP), spark plasma sintering (SPS).

\section{Összefoglalás}

Az alumínium-oxinitrid (AlON) kerámiaanyagok hő- és kémiai stabilitása rendkívüli, éppen ezért széleskörüen alkalmazzák különféle iparágakban. Ebben a cikkben röviden összefoglaljuk és összehasonlítjuk a napjainkban használatos főbb AlON-előállítási eljárásokat, kitérve a módszerek előnyeire és hátrányaira. Habár napjainkban a megnövekedett ipari kereslet következtében intenzív fejlesztések és kutatások folynak AlON-kerámiák előállítására, még mindig igény van olyan átfogó kutatásra, újfajta porszintézis és megmunkálás kidolgozására, melynek segítségével költséghatékonyabban és nagyobb mennyiségben lehetne előállítani tömör, ellenálló, átlátszó kerámiákat. Emellett a szinterelési körülmények és az átmeneti folyadékfázisú szinterelés optimalizálása is szükséges lépés.

Kulcsszavak: AlON, átlátszó kerámiák, meleg izosztatikus préselés (HIP), szikrakisüléses szinterelés (SPS).

\section{Bevezetés}

Az AlON-kerámiát az 1970-es években fedezték fel, amikor japán, amerikai és francia kutatók kimutatták, hogy alumínium-oxidhoz nitrogént adagolva egy új, spinelszerü fázis alakul ki. Ezt az átlátszó alumínium-oxinitrid kerámiaanyagot nevezték el később AlON-nak. A kerámiaanyag rendkívül egyedi tulajdonságokkal rendelkezett, ami kiválóan alkalmassá tette a legkülönfélébb ipari alkalmazásokra. Jelenleg a piacon elérhető AlON-por szemcsemérete átlagosan 150-200 $\mu \mathrm{m}$ között mozog, azonban újfajta eljárások kidolgozásával ez a szemcseméret csökkenthető, így a kerámia tulajdonságai is javulnak. Problémát okoz azonban, hogy a kerámiaanyag nagy keménysége miatt az utólagos megmunkálása és polírozása is igen költséges folyamat [1].

Az AlON-kerámia egyedi tulajdonságai a speciális kristályszerkezetében rejlenek. Általános- 
ságban elmondható, hogy az oxigénatom nitrogénnel történő helyettesítése az $\mathrm{Al}_{2} \mathrm{O}_{3}$-ban, vagy fordítva, oxigén bevitele az AlN-fázisba egy teljesen új, stabil fázis kialakulását eredményezi, amelynek különböző a kristályszerkezete és a tércsoport-szimmetriája: romboéderes $\mathrm{a}-\mathrm{Al}_{2} \mathrm{O}_{3}$, köbös AION vagy hexagonális AIN. Az AlON köbös, spinelszerű szerkezete alapján nitrogénnel stabilizált, köbös alumínium-oxidnak tekinthető. Sok tulajdonsága összevethető az a- $\mathrm{Al}_{2} \mathrm{O}_{3}$-éval, azonban a köbös szerkezetének köszönhetően megfelelő megmunkálással polikristályos, teljesen tömör és átlátszó anyag állítható elő [2]. Más tulajdonságai, úgymint a kis dielektromos veszteség azért alakulhat ki, mert a szemcsehatárokon a hőtágulási folyamat hatására nem keletkezik maradék feszültség. Az AlN egy érdekes anyag, mivel az elméleti hővezető képessége szobahőmérsékleten - $150 \mathrm{~W} /(\mathrm{m} \cdot \mathrm{K})$ - rendkívül nagy a dielektromos anyagokhoz képest, és ez összehasonlítható - vagy még nagyobb is lehet - sok fém esetével [3].

\section{Az AlON-előállítási módszerek átte- kintése}

Az utóbbi években számos módszert dolgoztak ki kutatócsoportok tömör, polikristályos, transzparens AlON-kerámiák gyártására; ezek fő jellemzőit az 1. táblázatban foglaltuk össze [2-14]. McCauley [2] és mtsai munkájukban $\mathrm{Al}_{2} \mathrm{O}_{3}-\mathrm{AlN}$ porkeverék reakciószinterelését végezték. Ezt az eljárást más kutatócsoportok is gyakran alkalmazzák [15, 16]. Az egyszerű szinterelés, a nagynyomású szinterelés, valamint a nagynyomású, meleg izosztatikus préselés (HIP) során AlONport használnak pórusmentes, tömör, átlátszó AlON-kerámiák kialakítására. Az AlON-porokat általában $\mathrm{Al}_{2} \mathrm{O}_{3}$ és AlN porok reagáltatásával vagy $\mathrm{Al}_{2} \mathrm{O}_{3}$ karbotermális redukciójával hozzák létre. Azonban a különböző módszerekkel előállított AlON keménysége, rugalmassági modulusa, valamint szakítószilárdsága jelentősen különbözött, amit több tanulmányban publikáltak [17, 18].

1. táblázat. Az AlON-előállítási módszerek összefoglalása és jellemzői

\begin{tabular}{|c|c|c|c|c|}
\hline Módszer & Fő jellemzők & Előnyök & Hátrányok & Hiv. \\
\hline Szinterelés & $\begin{array}{l}\text { Szinterelés nagy hőmér- } \\
\text { sékleten, atmoszférikus } \\
\text { nyomáson }\end{array}$ & $\begin{array}{l}\text { - Egyszerű } \\
\text { - Költséghatékony }\end{array}$ & $\begin{array}{l}\text { - Nagyobb hőmérséklet } \\
\text { szükséges, mint a nagy- } \\
\text { nyomású eljárásoknál }\end{array}$ & [4] \\
\hline $\begin{array}{l}\text { Nagy hőmérsék- } \\
\text { letü melegprése- } \\
\text { lés (HP) }\end{array}$ & $\begin{array}{l}\text { Egytengelyü nyomás és } \\
\text { nagy hőmérséklet együt- } \\
\text { tes alkalmazása }\end{array}$ & $\begin{array}{l}\text { - Egyszerü } \\
\text { - Nagy sürüségü, jó minőségű } \\
\text { termék állítható elő }\end{array}$ & $\begin{array}{l}\text { - Drága (nagy nyomás és } \\
\text { nagy hőmérséklet) } \\
\text { - Csak egyszerú formájú } \\
\text { termékek gyárthatók }\end{array}$ & [5] \\
\hline $\begin{array}{l}\text { Nagy hőmérsék- } \\
\text { letü meleg izosz- } \\
\text { tatikus préselés } \\
\text { (HIP) }\end{array}$ & $\begin{array}{l}\text { Nagy hőmérséklet és } \\
\text { hidrosztatikus nyomás } \\
\text { alkalmazása a porok } \\
\text { tömörítésére }\end{array}$ & $\begin{array}{l}\text { - Nagy sűrűségű, jó minőségű } \\
\text { termék állítható elő } \\
\text { - A porok tömörítése rövi- } \\
\text { debb idő alatt és kisebb } \\
\text { hőmérsékleten kivitelezhető } \\
\text { a hagyományos szinterelési } \\
\text { módszerekhez képest }\end{array}$ & $\begin{array}{l}\text { - Drága (nagy nyomás és } \\
\text { nagy hőmérséklet) } \\
\text { - Bonyolult a gyártási } \\
\text { folyamat } \\
\text { - Kis mennyiségű termék } \\
\text { állítható elő }\end{array}$ & {$[6,7]$} \\
\hline $\begin{array}{l}\text { Szikrakisüléses } \\
\text { szinterelés (SPS) }\end{array}$ & \begin{tabular}{|l|} 
Az eljárás során nagy \\
nyomáson, impulzusos \\
áram hatására kialakuló, \\
nagy hőmérsékleten \\
történik a minták szin- \\
terelése, vákuumban
\end{tabular} & $\begin{array}{l}\text { - Gyors felfütés } \\
\text { - Sokféle anyag szinterelése } \\
\text { lehetséges } \\
\text { - A porok tömörítése rövi- } \\
\text { debb idő alatt és kisebb } \\
\text { hőmérsékleten kivitelezhető } \\
\text { a hagyományos szinterelési } \\
\text { módszerekhez képest }\end{array}$ & $\begin{array}{l}\text { - Bonyolult a készülék, } \\
\text { ezért a minták formájá- } \\
\text { nak kialakítása korláto- } \\
\text { zott } \\
\text { - Nehéz müködtetés } \\
\text { - Drága, impulzusos áram- } \\
\text { generátor szükséges }\end{array}$ & [8-10] \\
\hline $\begin{array}{l}\text { Karbotermális } \\
\text { szintézis (CT) }\end{array}$ & $\begin{array}{l}\text { Az eljárásban grafitke- } \\
\text { mencében szinterelik a } \\
\text { mintákat, különböző hő- } \\
\text { mérsékleten (1700-1860 } \\
\left.{ }^{\circ} \mathrm{C}\right) \text { és nyomáson }(0,1-10 \\
\text { MPa), } \mathrm{N}_{2} \text {-gázban }\end{array}$ & $\begin{array}{l}\text { - Egyszerű } \\
\text { - Költséghatékony } \\
\text { - Nagyon finom szemcsés } \\
\text { porok állíthatók elő } \\
\text { - Kicsi a fém szennyezőanya- } \\
\text { gok koncentrációja }\end{array}$ & $\begin{array}{l}\text { - Nagyobb hőmérséklet } \\
\text { és hosszabb reakcióidő } \\
\text { szükséges } \\
\text { - Bonyolult termikus bom- } \\
\text { lási folyamatok } \\
\text { - Szénnel való szennye- } \\
\text { ződés }\end{array}$ & [13] \\
\hline $\begin{array}{l}\text { Közvetlen nitri- } \\
\text { dálás }\end{array}$ & $\begin{array}{l}\text { Termokémiai kezelés, } \\
\text { mely során } \mathrm{Al}-\mathrm{Al}_{2} \mathrm{O}_{3} \text { por- } \\
\text { keveréket használnak }\end{array}$ & $\begin{array}{l}\text { - Egyszerű } \\
\text { - Költséghatékony }\end{array}$ & $\begin{array}{l}\text { - Kisebb átlátszóság } \\
\text { - Rosszabb termékminőség }\end{array}$ & [14] \\
\hline
\end{tabular}


Az előzőekben említett módszerek fő hátránya a nagy szinterelési hőmérséklet és a hosszú szinterelési idő, így gazdaságosság szempontjából előnyös lehet ezek csökkentése, illetve lerövidítése anélkül, hogy a kerámia mechanikai tulajdonságaira káros hatással lenne.

\section{Az AlON-előállítási módszerek fej- lesztésének jelenlegi helyzete}

A legelterjedtebben használt és legígéretesebb eljárások az iparban a melegpréselés (HP), a már említett meleg izosztatikus préselés (HIP) és a szikrakisüléses szinterelés (SPS). Shan és mtsai. [9] SPS-módszerrel állítottak elő AlON-kerámiát. Kísérleteikben $\mathrm{Al}_{2} \mathrm{O}_{3}$ - és AlN-porkeveréket használtak kiindulási anyagként. A szinterelést 1400 és $1650{ }^{\circ} \mathrm{C}$ között végezték $15-45$ percig $40 \mathrm{MPa}$ nyomáson $\mathrm{N}_{2}$-atmoszféra alatt. Azt találták, hogy az AlON-fázis az $1430{ }^{\circ} \mathrm{C}$ hőmérséklet felett szinterelt mintákban kezdett kialakulni. A kezdeti fázisok ( $\mathrm{Al}_{2} \mathrm{O}_{3}$ és $\left.\mathrm{AlN}\right)$ teljes átalakulása az $1650{ }^{\circ} \mathrm{C}$-on 30 percig $40 \mathrm{MPa}$ nyomáson szinterelt mintáknál történt meg. Ezen kívül a nagy SPS-hőmérséklet és a kis felfütési sebesség együttesen nagyobb mennyiségű AlON-fázis kialakulását eredményezte ugyanannyi megmunkálási idő alatt.

A szikrakisüléses szinterelés hőmérsékletének $1430^{\circ} \mathrm{C}$-ról $1650^{\circ} \mathrm{C}$-ra történő növelésével szintén növelhető az AlON-fázis keletkezésének sebessége.

Habár a legtöbb tanulmány azt állítja, hogy az $\mathrm{Al}_{2} \mathrm{O}_{3}$ - és AlN-porok reagáltatásakor csak $1650{ }^{\circ} \mathrm{C}$ felett és 2 óra szinterelési idővel érhető el a tiszta és tömör AlON-fázis keletkezése, azonban az SPSsel $1650{ }^{\circ} \mathrm{C}$-on, 20 perc alatt, $50{ }^{\circ} \mathrm{C} /$ perc felfütési sebességgel már nagyobb mint $98,5 \%$ relatív sürűségű, tömör AlON-kerámia nyerhető [9]. Így elmondható, hogy megfelelő minőségű AlON-kerámiák SPS-módszerrel már kisebb hőmérsékleteken $\left(<1650{ }^{\circ} \mathrm{C}\right)$, illetve rövidebb idő (5-15 perc) alatt is előállíthatók. A minták keménysége és relatív sűrűsége kissé megnövekedett, és szemcseméret-növekedést is megfigyeltek a növekvő reakcióidővel. Annak ellenére, hogy a relatív sürűség megnövekedett és a pórusok fokozatosan eltűntek, az AlON szemcsemérete növekedett a szinterelési idő növelésével. A nagyobb szemcsék hatására a minták hajlítószilárdsága és rugalmassági modulusa kisebb lett.

Azonban tömör AlON-kerámiák nem állíthatók elő szinterelési adalékanyagok alkalmazása nélkül, akár vákuumban, akár $\mathrm{N}_{2}$-atmoszféra alatt végezzük a szinterelést. Kutatások azt is kimutat- ták, hogy a vákuumban szinterelt AlON-kerámiák mechanikai tulajdonságai jobbak a $\mathrm{N}_{2}$-atmoszférában készítettekhez képest [10, 11]. Adalékanyagok alkalmazásával az AlON-kerámiák szinterelés után visszamaradó porozitása minimálisra csökkenthető, kisebb szinterelési hőmérséklet alkalmazása elegendő a megfelelő és tömör kerámiaanyag kialakításához. Azonban fontos a másodlagos fázisok kialakulásának az elkerülése, amelyek rontanák a kerámia átlátszóságát [12].

Chen és mtsai. [7] HIP-módszer segítségével állítottak elő nagy átlátszóságú, tiszta AlON-kerámiákat mintegy $20 \mu \mathrm{m}$ átlagos szemcseméretű, finom porból. Azt találták, hogy az adalékanyagoknak nagy szerepük van a kerámiák porozitásának csökkentésében. A HIP-es szinterelés alatt a pórusok sikeresen eltűntek. Azt is észrevették, hogy csak $\mathrm{Y}_{2} \mathrm{O}_{3}$ - vagy $\mathrm{La}_{2} \mathrm{O}_{3}$-adalék alkalmazása helyett a $\mathrm{Y}_{2} \mathrm{O}_{3} / \mathrm{La}_{2} \mathrm{O}_{3}$ együttes alkalmazása sokkal hatásosabbnak bizonyult a megfelelő minőségü, pórusmentes kerámiák kialakításához. Az így kifejlesztett AlON-kerámiák átlátszósága elérte a 85\%-ot 1100 nm hullámhosszon, még kis adalékanyag-koncentráció esetén is.

$\mathrm{Az}$ átlátszósági értékek függtek az előszinterelt AlON-minták mikroszerkezetétől is. A megfelelően nagy átlátszóságú, tömör AlON-mintadarabok (4,2 mm vastag) kialakításához 0,08\% tömegarányú $\mathrm{Y}_{2} \mathrm{O}_{3}$-ra és $0,02 \% \quad \mathrm{La}_{2} \mathrm{O}_{3}$-ra volt szükség, ami sokkal kisebb az irodalomban eddig publikált 0,12\% $\mathrm{Y}_{2} \mathrm{O}_{3}$ és 0,09\% $\mathrm{La}_{2} \mathrm{O}_{3}$-értékekhez képest nyomásmentes szinterelés alkalmazásakor. Az AlON-kerámiák relatív sűrüségeit és transzparenciaértékeit hasonlítjuk össze az 1. ábrán.

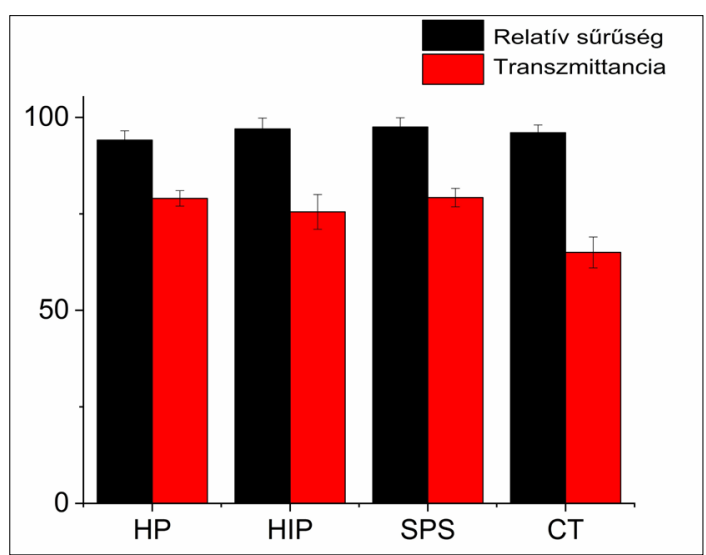

1. ábra. Különbözö eljárásokkal készített AlON-minták relatív sürüsége és átlátszósági értékei (a látható fény hullámszám-tartományában). A relatív sürüséget az AlON elméleti sürüségéhez viszonyítva számoltuk, amely $3,71 \mathrm{~g} / \mathrm{cm}^{3}$ 
Látható, hogy a különböző módszerekkel készített AlON-minták relatív sűrüsége mindegyik esetben megközelíti a 100\%-ot, ami azt bizonyítja, hogy mindegyik esetben tömör és tiszta kerámiaanyagot lehet nyerni.

Az irodalmi adatok részletes áttanulmányozásával azt tapasztaltuk, hogy a különféle eljárásokkal készített AlON-kerámiák átlátszósága jelentősen különbözött. A legkisebb átlátszósági százalékokat a CT-módszer esetében mérték ( 65\%), míg a többi módszernél a látható fény hullámhossz-tartományában az átlátszóság jobb volt, 75\% feletti. A legnagyobb értékeket az SPS-módszernél kapták $(79,2 \pm 2,4 \%)$.

Napjainkban számos cég gyárt AlON-kerámiát különböző felhasználási területekre. Az átlátszó kerámiaanyagon a beeső, az átmenő és a visszaverődő fénysugár útját a 2 . ábrán mutatjuk be.

A beeső fénysugár és az izotrop, polikristályos kerámiaanyagok közötti kölcsönhatás tovább vizsgálható a fény útjának a szemcsehatárokon történő megtörésének, illetve áthaladásának mechanizmusával. A fénytörés általában a kerámia felületén, illetve az egyes szemcsék határain következik be, ami az anyag törésmutatójának változását okozza, ezáltal hatással van annak optikai transzmittanciájára (3. ábra).

A 4. és 5. ábrán láthatóak a különböző előállítási módszerek során alkalmazott jellemző hőmérsékletek, illetve az előállított átlátszó kerámiák keménységértékei. Az ábrákból látható, hogy az SPS-módszer esetében a legkisebb a szinterelési hőmérséklet és a legnagyobb az előállított kerámiák keménysége. Az AlON-ok polikristályos kerámiaanyagok, amelyek az átláthatóságuk és jó mechanikai tulajdonságaik miatt sok területen kiválóan alkalmazhatók. Ezek lehetnek valós

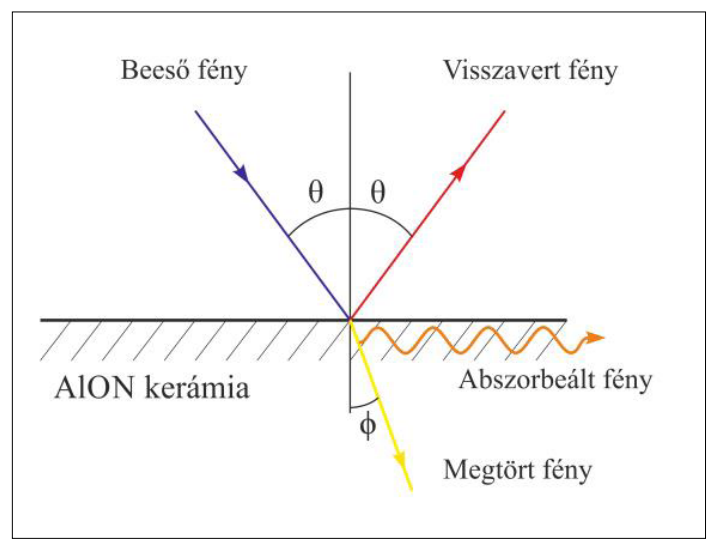

2. ábra. Az átlátszó anyagon visszaverődött és megtört fénysugár útjának sematikus ábrázolása

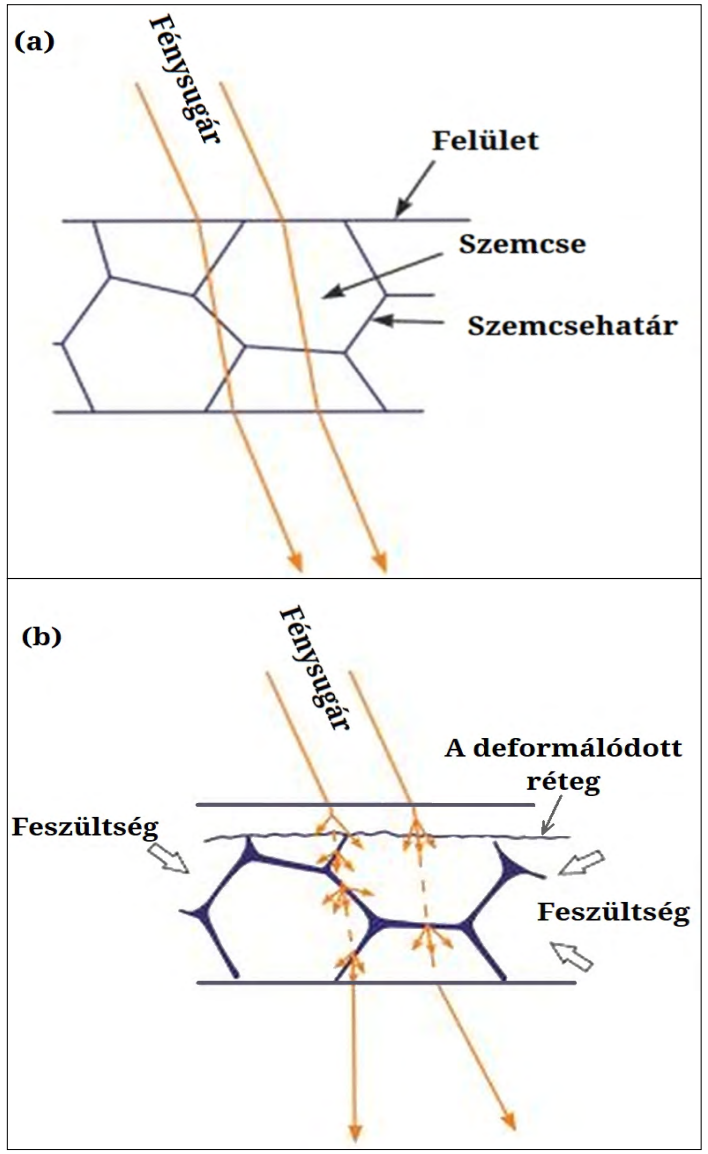

3. ábra. A beeső fénysugár és az izotróp, polikristályos kerámiaanyag közötti kölcsönhatás sematikus ábrázolása. (a) Ideális, homogén polikristályos anyag, elméleti sürüséggel: a fény nem szóródik a szemcsehatárokon. b) Belső feszültséggel rendelkező polikristályos kerámiaanyag: a fény szóródik a nem homogén kristályszemcsék határain

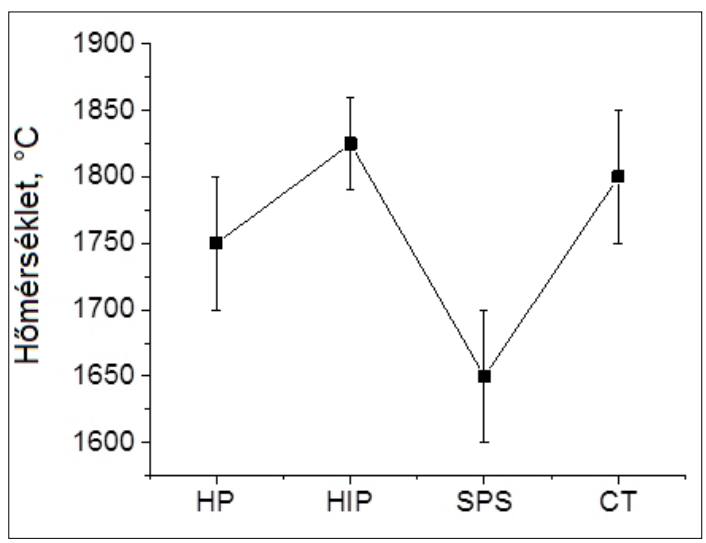

4. ábra. Különböző eljárások során alkalmazott általános szinterelési hőmérséklet tartományok 
idejü diagnosztikai megfigyelések, átlátszó páncélzatok, elektromágneses (EM) védőkupolák és ablakok, katonai repülőgépek és infravörös (IR) áteresztő ablakok, félgömb alakú kupolák, lézer-

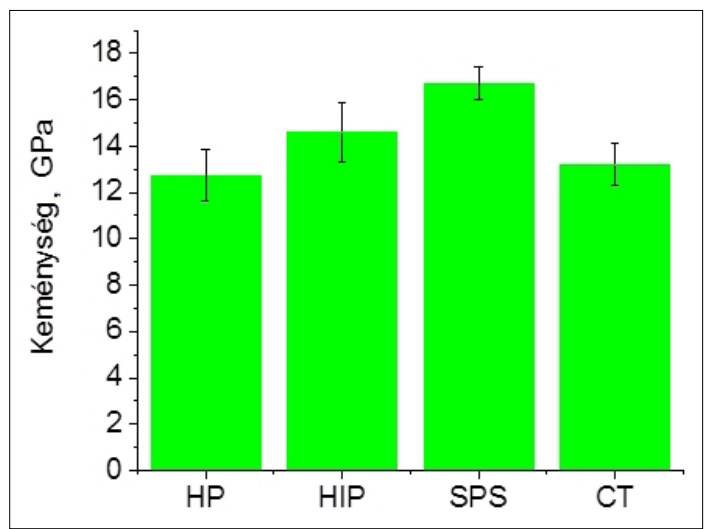

5. ábra. Különböző eljárásokkal készített AlON-minták keménységértékei

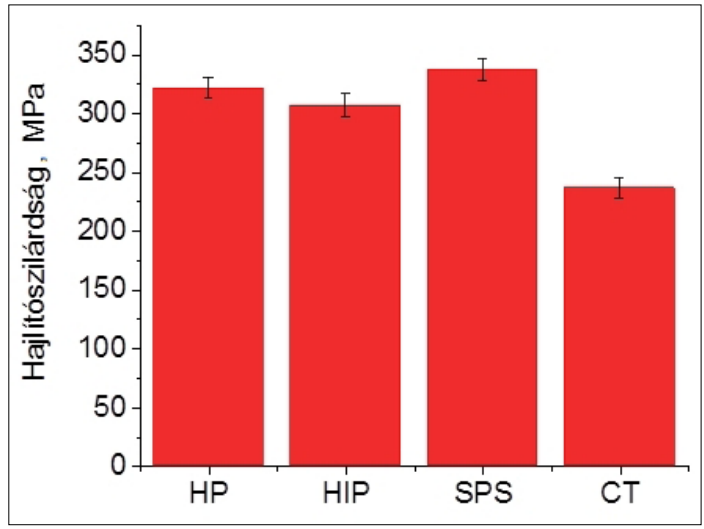

6. ábra. Különbözö eljárásokkal készített AlON-minták szilárdságértékei

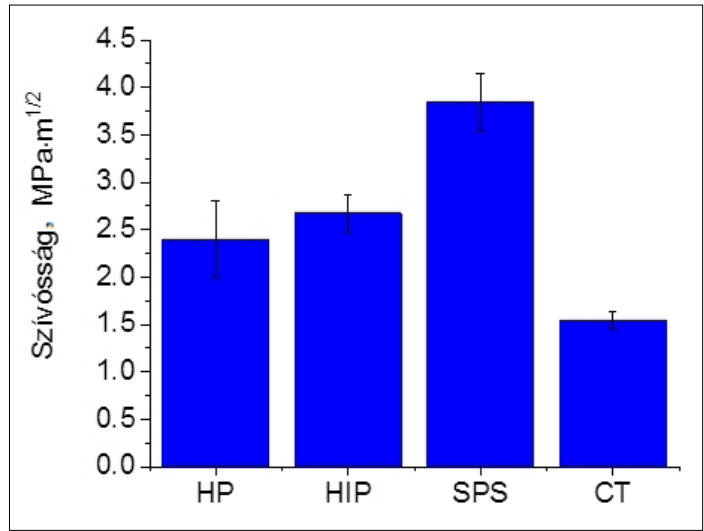

7. ábra. Különbözö eljárásokkal készített AlON-minták szakitószilárdság-értékei ablakok, katonai repülőgépek lencséi, félvezetőipari alkalmazások és szkennerablakok.

A 6. ábrán a különböző módokon készített AlON-minták szilárdságértékeit mutatjuk be. Látható, hogy a legnagyobb szilárdsággal az SPS-eljárással készített minta rendelkezik, valamint a HP- és HIP-módszerek esetében az eltérés nem számottevő. A legkisebb szilárdságú mintákat a karbotermális eljárás szolgáltatta.

Másik fontos mechanikai jellemző, ami a megfelelő ipari alkalmazáshoz elengedhetetlen, a töréssel szembeni szívósság vagy a szakítószilárdság. Ezen paraméter változása a különböző eljárásokkal készített mintáknál a 7. ábrán látható. Ebben az esetben is hasonló tendencia figyelhető meg, mint a hajlítószilárdság esetében.

Zhao és mtsai. [5] tanulmányozták a különféle adalékanyagok, úgymint SiC és $\mathrm{ZrN}$ nanorészecskék hatását az AlON-kerámiák mechanikai tulajdonságaira. Publikációjukban leírták, hogy a nanorészecskék beépülnek az AlON mikrorészecskék határfelületei közé, ezáltal csökkentik a minták porozitását és megváltoztatják a törési mechanizmust. Az adalékanyagok jelenléte kis mennyiségben (5-8\% tömegarányban) is megnövelte a minták relatív sürűségét, keménységét, javította a hajlítószilárdságát, valamint a szívósságát is. Li és mtsai. [11] SPS-eljárással készítettek átlátszó AlON-kerámiát. Az eredményeik azt mutatták, hogy nem állítható elő tökéletesen tömör AlON-kerámia bizonyos mennyiségű adalékanyag jelenléte nélkül. Az adalékanyagok segítségével lecsökkenthető a szinterelési hőmérséklet és a szinterelési idő, azonban képződhetnek másodlagos fázisok az eljárás alatt, amik negatívan hathatnak a kerámia átlátszóságára, illetve a mechanikai tulajdonságaira.

\section{Következtetések}

A tudományos irodalom átfogó tanulmányozása alapján és az AlON átlátszó kerámiák gyártásának jelenlegi állása szerint kijelenthetjük, hogy a napjainkban elérhető és alkalmazott módszerek még mindig drágák, valamint energia- és időigényesek. Nagy hőmérséklet (1600-1900 ํㅡ) fenntartása szükséges hosszú időn keresztül, hogy a megfelelő fázisátalakulás és a porok kellő sűrűsége kialakuljon. Munkánk során olyan környezetbarát és gazdaságos AlON-előállítási eljárást tervezünk kidolgozni, melyben kisebb hőmérsékleten vagy rövidebb szinterelési idő alatt alakítható ki a megfelelő tömörségű, átlátszó, AlON-fázisú kerámia. Ezáltal kevesebb energia felhasználására 
lenne szükség. Emellett tervezzük az alumínium hulladékok (kannák, flakonok) újrahasznosítását a gyártási folyamatban mint alumíniumforrást, és így környezettudatossá tenni az eljárást.

\section{Köszönetnyilvánítás}

A kézirat az ALON-kerámiák környezetkímélő előállítása és vizsgálata (NNE129976-NKFIH) projekt támogatásával készült.

\section{Szakirodalmi hivatkozások}

[1] McCauley J. W., Patel P., Chen M., Gilde G., Strassburger E., Paliwal B., Ramesh K. T., Dandekar D. P.: AlON: A brief history of its emergence and evolution. Journal of the European Ceramic Society, 29/2. (2009) 223-236.

https://doi.org/10.1016/j.jeurceramsoc.2008.03.046

[2] McCauley J. W., Corbin N. D.: Phase Relations and Reaction Sintering of Transparent Cubic AIuminium Oxynitride Spine1 (AION). Journal of the American Ceramic Society, 62/9-10. (1979) 476479 .

https://doi.org/10.1111/j.1151-2916.1979. tb19109.x

[3] McCauley J. W.: Structure and Properties of Aluminum Nitride and AlON Ceramics. Army Research Laboratory Aberdeen Proving Ground, (2002) MD 210053069.

https://doi.org/10.1016/B0-08-043152-6/00028-0

[4] Shan Y., Zhang Z., Sun X., Xu J., Qin Q., Li J.: Fast densification mechanism of bimodal powder during pressureless sintering of transparent AlON ceramics. Journal of the European Ceramic Society, 36/3. (2016) 671-678.

https://doi.org/10.1016/j.jeurceramsoc.2015.10.026

[5] Zhang N., Liang B., Wang X. Y., Kan H. M., Zhua K. W., Zhao X. J.: The pressureless sintering and mechanical properties of AlON ceramic. Materials Science and Engineering A, 528/19-20. (2011) 6259-6262.

https://doi.org/10.1016/j.msea.2011.04.072

[6] Jiang N., Liu Q., Xie T., Ma P., Kou H., Pan Y., Li J.: Fabrication of highly transparent AlON ceramics by hot isostatic pressing post-treatment. Journal of the European Ceramic Society, 37/13. (2017) 4213-4216.

https://doi.org/10.1016/j.jeurceramsoc. 2017.04 .028

[7] Chen F., Zhang F., Wang J., Zhang H., Tian R., Zhang Z., Wang S.: Hot isostatic pressing of transparent AlON ceramics with $\mathrm{Y}_{2} \mathrm{O}_{3} / \mathrm{La}_{2} \mathrm{O}_{3}$ additives. Journal of Alloys and Compounds, 650. (2015) 753-757.

https://doi.org/10.1016/j.jallcom.2015.08.028

[8] Xue J. M., Liu Q., Xiu T., Ma L., Fang M., Gui L.: HotPressed Translucent Aluminum Oxynitride (AlON) Ceramics. Key Engineering Materials, 368-372.
(2008) 450-452.

https://doi.org/10.4028/www.scientific.net/ KEM.368-372.450

[9] Shan Y, Zhang Z., Sun X., Xu J., Qin Q., Li J.: Further experimental investigation on fast densification mechanism of bimodal powder during pressureless sintering of transparent AlON ceramics. Ceramics International, 43/11. (2017) 8195-8201. https://doi.org/10.1016/j.ceramint.2017.03.146

[10] Sahin F. C., Kanbur H. E., Apak B.: Preparation of AlON ceramics via reactive spark plasma sintering. Journal of the European Ceramic Society, 32/4. (2012) 925-929.

https://doi.org/10.1016/j.jeurceramsoc.2011.10.043

[11] Li X., Huang J., Luo J.: Progress and Challenges in the Synthesis of AlON Ceramics by Spark Plasma Sintering. Transactions of the Indian Ceramic Society, 76/1. (2017). 14-20. https://doi.org/10.1080/0371750X.2016.1257956

[12] Zientara D., Bucko M. M., Lis J.: Dielectric properties of aluminium nitride- $\gamma$-AlO materials. Journal of the European Ceramic Society, 27/13-15. (2007) 4051-4054.

https://doi.org/10.1016/j.jeurceramsoc.2007.02.093

[13] Zheng J., Forslund B.: Carbothermal Synthesis of Aluminium Oxynitride (ALON) Powder: Influence of Starting Materials and Synthesis Parameters. Journal of the European Ceramic Society, 15/11. (1995) 1087-1100.

https://doi.org/10.1016/0955-2219(95)00078-9

[14] Su M., Zhou Y., Wang K., Yang Z., Cao Y., Hong M.: Highly transparent AlON sintered from powder synthesized by direct nitridation. Journal of the European Ceramic Society, 35. (2015) 1173-1178.

[15] Kim Y. W., Park B. H., Park H. C., Lee Y. B., Oh K. D., Riley F.: Sintering, microstructure and mechanical properties of AlON-AlN particulate composites. British Ceramics Transactions, 97/3. (1998) 97-104.

[16] Kim Y. W., Park H. C., Lee Y. B., Oh K. D., Stevens R.: Reaction sintering and microstructural development in the system $\mathrm{Al}_{2} \mathrm{O}_{3}-\mathrm{AlN}$. Journal of the European Ceramic Society, 21/13. (2001) 23832391. https://doi.org/10.1016/S0955-2219(01)00200-X

[17] Trabelsi R., Treheux D., Goeuriot-Launay D., Goeuriot P., Thevenot F., Orange G. et al.: Friction, wear resistance and mechanical properties of an alumina- $\gamma$-aluminum oxynitride composite (ALUMINALON). In: High Tech Ceramics. (ed. P. Vincenzini) Elsevier Sci. Pub., (1987) 2683-2695.

[18] Berriche Y., Vallayer J., Trabelsi R., Treheux D.: Severe wear mechanisms in $\mathrm{Al}_{2} \mathrm{O}_{3}-\mathrm{AlON}$ ceramic composites. Journal of the European Ceramic Society, 20/9. (2000) 1311-1318.

https://doi.org/10.1016/S0955-2219(99)00294-0 